\title{
Stability-indicating HPLC-PDA assay for simultaneous determination of paracetamol, thiamine and pyridoxal phosphate in tablet formulations
}

\author{
AMIR ALI ${ }^{1}$ \\ MUHAMMAD MAKSHOOF ATHAR ${ }^{1}$ \\ MAHMOOD AHMED ${ }^{1}$ \\ KASHIF NADEEM ${ }^{2}$ \\ GHULAM MURTAZA ${ }^{2}$ \\ UMAR FAROOQ ${ }^{*}$ \\ MUHAMMAD SALMAN ${ }^{1}$ \\ ${ }^{1}$ Institute of Chemistry \\ University of the Punjab, Lahore 54590 \\ Pakistan \\ ${ }^{2}$ Schazoo Pharmaceutical Laboratories \\ Lahore-Jaranwala Road, Sheikhupura \\ Pakistan
}

\begin{abstract}
With the increased number of multi-drug formulations, there is a need to develop new methods for simultaneous determinations of drugs. A precise, accurate and reliable liquid chromatographic method was developed for simultaneous determination of paracetamol, thiamine, and pyridoxal phosphate in pharmaceutical formulations. Separation of analytes was carried out with an Agilent Poroshell C18 column. A mixture of ammonium phosphate buffer $(\mathrm{pH}=3.0)$, acetonitrile and methanol in the ratio of 86:7:7 $(V / V / V)$ was used as the mobile phase pumped at a flow rate of $1.8 \mathrm{~mL} \mathrm{~min}^{-1}$. Detection of all three components, impurities and degradation products was performed at the selected wavelength of $270 \mathrm{~nm}$. The developed method was validated in terms of linearity, specificity, precision, accuracy, $L O D$ and $L O Q$ as per ICH guidelines. Linearity of the developed method was found in the range $17.5-30 \mu \mathrm{g} \mathrm{mL}^{-1}$ for thiamine, 35-60 $\mathrm{g} \mathrm{mL}^{-1}$ for pyridoxal phosphate and 87.5$150 \mu \mathrm{g} \mathrm{mL} \mathrm{m}^{-1}$ for paracetamol. The coefficient of determination was $\geq 0.9981$ for all three analytes. The proposed HPLC method was found to be simple and reliable for the routine simultaneous analysis of paracetamol, thiamine and pyridoxal phosphate in tablet formulations. Complete separation of analytes in the presence of degradation products indicated selectivity of the method.
\end{abstract}

Keywords: paracetamol, thiamine, pyridoxine phosphate, degradation, HPLC-PDA

With advancement in research and development in the pharmaceutical industry, the role and production of multicomponent drug formulations is increasing steadily. Recent advances in pharmaceutical sciences have proven that the one drug-one target lock and key model is limited (1). In many complicated and refractory diseases hardly any single drug has shown satisfactory benefits. However, using a combination of drugs has offered more satisfactory results (2). Multidrug pharmaceutical fixed dose combinations contain

\footnotetext{
*Correspondence; umar.chem@pu.edu.pk
} 
a)<smiles></smiles>

b)<smiles>Cc1ncc(COP(=O)(O)O)c(C=O)c1O</smiles>

c)<smiles>CC(=O)Nc1ccc(O)cc1</smiles>

Fig. 1. Chemical structures of: a) thiamine, b) pyridoxal phosphate, and c) paracetamol.

different active pharmaceutical ingredients (API) for the treatment of pain; the components mostly include aspirin and paracetamol with codeine, barbiturates, caffeine, derivatives of pyrazolones, pentazocine and vitamins that can enhance the pharmacological effectiveness of these fixed dose combinations (3). The different API components have different modes of action; they sometimes act as synergists with more efficiency. In multidrug fixed dose combinations each API is usually present in a dose lower than in the single-component formulation, lowering the organ burden (4). Paracetamol (acetaminophen, $N$-acetyl- $p$-aminophenol), thiamine (2-[3-[(4-amino-2-methylpyrimidin-5-yl)methyl]4-methyl-1,3-thiazol-3-ium-5-yl, B1] ethanol, $\mathrm{C}_{12} \mathrm{H}_{17} \mathrm{~N}_{4} \mathrm{OS}^{+}$) and pyridoxal phosphate ([(4-formyl-5-hydroxy-6-methylpyridin-3-yl)methoxy] phosphonic acid, $\mathrm{C}_{8} \mathrm{H}_{10} \mathrm{NO}_{6} \mathrm{P}$, B6) are the analytes of interest in the mixture in our research (5-7).

A literature survey revealed that different analytical methods were available for the estimation of paracetamol, individually or in fixed dose combinations other than vitamins $\mathrm{B}_{1}$ and $\mathrm{B}_{6}$, by various methods including voltammetry, LC-MS-MS, micellar electrokinetic capillary chromatography and flow injection solid phase spectrometry (8-10). It was also found that vitamins $B_{1}$ and $B_{6}$ were estimated individually or in pharmaceutical combinations other than paracetamol using spectroscopic and chromatographic techniques coupled to various detectors such as UV-visible, fluorometric and electrochemical ones (11-16).

To the best of our knowledge, several RP-HPLC methods are available for the estimation of paracetamol, thiamine and pyridoxal phosphate (Fig. 1), individually or in combination with other drugs in fixed dose pharmaceutical formulations but no stability indicating assay method has been reported (17-21). The present research is aimed at developing a rapid, sensitive and stability indicating liquid chromatographic (HPLC) method for the simultaneous determination of paracetamol, thiamine, and pyridoxal phosphate. The proposed HPLC method was validated according to ICH guidelines and forced degradation studies were performed to show the stability-indicating nature of the method (22-24).

\section{EXPERIMENTAL}

\section{Chemicals and reagents}

Paracetamol (PRML), thiamine (B1), and pyridoxal phosphate (B6) working standards were donated by Schazoo Pharmaceutical Laboratories Ltd. (Pakistan). Diammonium hydrogen phosphate and phosphoric acid ( $85 \%$ ) were obtained from Sigma Aldrich, USA. Methanol and acetonitrile were purchased from Merck, Germany. In experimental work, 
distilled water $\left(18 \mu \mathrm{S} \mathrm{m}^{-1}\right)$ was used, prepared in our own lab using the GenPure water system (Thermo Scientific, USA). The solvents and chemicals used during analysis were of HPLC grade. Multi drug formulations in tablet form, containing paracetamol, thiamine, and pyridoxal phosphate were collected from the local market shelves (Neuro Bedoxine Plus tablets, each film coated tablet containing: vitamin B1 50 mg, vitamin B6 100 mg, vitamin B12 $100 \mathrm{mg}$, paracetamol 250 mg, Schazoo Pharmaceutical Laboratories, Pakistan) in Lahore, the capital city of Pakistan.

\section{Chromatography}

An LC-20 liquid chromatograph (Shimadzu, Japan) with diode array detector (SPDM20A), online degasser (DGU-20A5) equipped with Agilent Poroshell C18 column (5 $\mu \mathrm{m}$, $4.6 \times 250 \mathrm{~mm}$ ) was employed to separate the components. A mixture of ammonium phosphate buffer $(\mathrm{pH}=3.0)$, acetonitrile and methanol, 86:7:7 volume ratio, was used as the mobile phase. Mobile phase was sonicated for $10 \mathrm{~min}$ to degas before use. The finally selected optimized conditions were as follows: injection volume $10 \mu \mathrm{L}$, adjusted flow rate 1.8 $\mathrm{mL} \mathrm{min}{ }^{-1}$, column temperature $40^{\circ} \mathrm{C}$, API detection at $270 \mathrm{~nm}$. Standard and sample solutions were filtered using a nylon filter $(0.45 \mu \mathrm{m}$, Sartorius, Germany) before analysis.

\section{Standard and working solutions}

Standard stock solutions (1000 $\left.\mu \mathrm{g} \mathrm{mL}^{-1}\right)$ of PRML, B1 and B6 were prepared in methanol and sonicated for $10 \mathrm{~min}$. The stock standard solution was diluted with the mobile phase to prepare individual working standard solutions. Amounts of $250 \mathrm{mg}$ PRML, $50 \mathrm{mg}$ B1 and $100 \mathrm{mg} \mathrm{B} 2$ were dissolved in methanol to a $100 \mathrm{~mL}$ volume; $5.0 \mathrm{~mL}$ of the above solution was diluted with the mobile phase to $100 \mathrm{~mL}$ to prepare a mixed standard solution with the final concentration of $125 \mu \mathrm{g} \mathrm{mL} \mathrm{m}^{-1} \mathrm{PRML}, 25 \mu \mathrm{g} \mathrm{mL} \mathrm{m}^{-1} \mathrm{~B} 1$ and $50 \mu \mathrm{g} \mathrm{mL} \mathrm{m}^{-1} \mathrm{~B}$.

\section{Sample preparation}

Ten tablets (Neuro Bedoxine Plus tablet containing $250 \mathrm{mg}$ PRML, $50 \mathrm{mg}$ B1 and $100 \mathrm{mg}$ B6, Schazoo Pharmaceutical Laboratories, Pakistan) were ground and the mass equivalent to one tablet was dissolved in methanol and the volume was made up to $100 \mathrm{~mL}$ with methanol. The working sample solution was prepared by 20 -fold dilution with the mobile phase.

\section{Forced degradation studies}

Forced degradation studies were performed with standard solutions of PRML, B1 and B6 having final concentrations of $125,25,50 \mu \mathrm{g} \mathrm{mL}^{-1}$, resp. Ten (10.0) $\mathrm{mL}$ of each standard solution was added into separate measuring flasks and treated with $10.0 \mathrm{~mL}$ of $\mathrm{NaOH}(0.1$ mol L-1 $), \mathrm{HCl}\left(0.1 \mathrm{~mol} \mathrm{~L}^{-1}\right)$, and $\mathrm{H}_{2} \mathrm{O}_{2}(15 \%, V / V)$ for $12 \mathrm{~h}$ to study the basic and acidic hydrolysis and oxidative stress, resp. Thermal and photolytic stress studies were performed after keeping the solid tablets at $100{ }^{\circ} \mathrm{C}$ for $6 \mathrm{~h}$ and exposing them to UV-light $(254 \mathrm{~nm})$ for $24 \mathrm{~h}$, resp.

\section{Method validation}

Validation of the developed method included precision, linearity, specificity, accuracy, limit of detection $(L O D)$, limit of quantification $(L O Q)$ and robustness (22). Conformity of 
chromatographic parameters, including the selectivity factor, tailing factor, resolution, theoretical plates, were also assessed while robustness was checked by deliberate changes in chromatographic conditions such as the flow rate $\left( \pm 0.1 \mathrm{~mL} \mathrm{~min}^{-1}\right)$, column temperature $\left( \pm 2{ }^{\circ} \mathrm{C}\right)$, wavelength $( \pm 2 \mathrm{~nm})$ and $\mathrm{pH}( \pm 0.1)$.

For accuracy of the proposed method, the tablet formulation was spiked with known amounts of API at $70 \%$ (175 mg PRML, $35 \mathrm{mg}$ B1 and $70 \mathrm{mg} \mathrm{B} 6$ ), 100 \% (250 mg PRML, 50 $\mathrm{mg} \mathrm{B1}$ and $100 \mathrm{mg} \mathrm{B}$ ) and $120 \%$ (300 mg PRML, $60 \mathrm{mg} \mathrm{B1}$ and $120 \mathrm{mg} \mathrm{B} 6)$ and analysis was performed after 20-fold dilution with the mobile phase. Percentage recoveries of PRML, B1 and B6 were assessed in triplicate and the results are presented as mean $\pm \mathrm{SEM}$. Precision of the proposed method was checked by injecting the standard solutions of PRML, B1 and B6 at three concentration levels (70, 100 and $120 \%$ as defined in recovery studies). To measure intra-day and inter-day precision, standard solutions were injected on the same day and on three consecutive days, resp.

Linearity of the proposed method was determined for PRML, B1 and B6 using standard solutions having concentrations 87-150 $\mu \mathrm{g} \mathrm{mL}^{-1}$ PRML, 17.5-30 $\mu \mathrm{g} \mathrm{mL}{ }^{-1} \mathrm{~B} 1$ and $35-60$ $\mu \mathrm{g} \mathrm{mL} \mathrm{L}^{-1} \mathrm{~B} 6$ and injected in triplicate to construct the calibration curve. $L O D$ and $L O Q$ were also determined from the calibration curves as $3.3 \sigma / \mathrm{S}$ and $10 \sigma / \mathrm{S}$, resp., with $\sigma$ being the standard deviation and $S$ the slope of the regression line.

Analysis of a placebo solution including gelatin $(40.0 \mathrm{mg})$, lactose $(14.0 \mathrm{mg})$, Avicel $(102.0 \mathrm{mg})$, primogel $(25.0 \mathrm{mg})$, talc $(15.0 \mathrm{mg})$ and magnesium stearate $(4.0 \mathrm{mg})$ was made to check the specificity of the proposed HPLC method. Specificity was also measured by forced degradation studies.

\section{Solution stability}

Stability of the sample and standard solutions was estimated against freshly prepared standard solutions at intervals of 12,24 and $48 \mathrm{~h}$ at room temperature.

\section{RESULTS AND DISCUSSION}

\section{Optimization of chromatographic conditions}

The first step in method development was the selection of appropriate wavelengths for different compounds having different wavelength absorption maxima. A spectrum in the range of 200-400 $\mathrm{nm}$ showed acceptable absorbance at a wavelength of $270 \mathrm{~nm}$ for each analyte (Fig. 2) under investigation, which was chosen for quantification.

Optimization of the mobile phase was performed with a solution containing water and acetonitrile or methanol. It was observed that peaks of these three analytes were not completely separated. Different combinations of methanol, acetonitrile and phosphate buffer of different $\mathrm{pH}(3.0,4.0,5.0,6.0$, and 7.0) were then tested to optimize the chromatographic conditions including the tailing factor, resolution, theoretical plates and retention times. Different $\mathrm{C}_{18}$ and $\mathrm{C}_{8}$ reversed phase columns were also tested including Venusil XBP C8, Hypersil ODS C18, ACE C8 and Agilent Poroshell C18 (Table I). Agilent Poroshell C18 $(5 \mu \mathrm{m}, 4.6 \times 250 \mathrm{~mm})$ reversed phase column with a mobile phase comprising phosphate buffer $(\mathrm{pH}=3.0) /$ methanol/acetonitrile $(86: 7: 7, \mathrm{~V} / \mathrm{V} / \mathrm{V})$ pumped at a flow rate of $1.8 \mathrm{~mL} \mathrm{~min}{ }^{-1}$ 


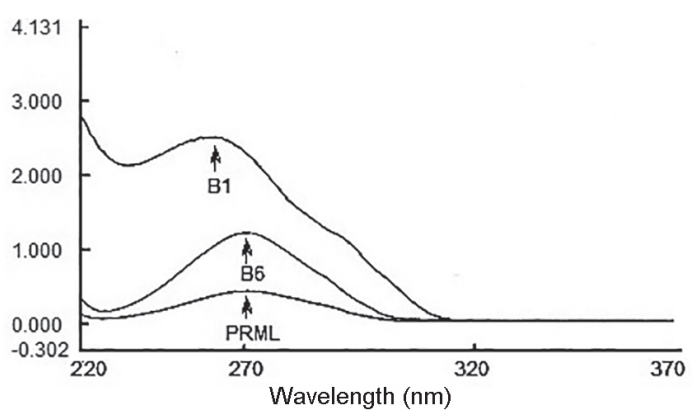

Fig. 2. Overlaid spectra of thiamine (B1), pyridoxal phosphate (B6), and paracetamol (PRML). mAU milli absorbance units.

afforded the best separation of PRML, B1 and B6. The respective retention times found were $1.89,2.41$ and $6.29 \mathrm{~min}$. Chromatographic parameters obtained under final conditions are summarized in Table II.

\section{Method validation}

For linearity assessment, six concentrations $(n=3)$ in the range of $70-120 \%$ of the label claim of B1, B6 and PRML were employed (Table III). Coefficients of determination $\left(R^{2}\right)$ were $\geq 0.998$. The results demonstrate linearity of the developed method over the specified ranges. The placebo sample, namely excipients, showed no peak. Therefore, the proposed method is specific for APIs in the tablet, as shown in the chromatogram (Fig. 3).

Accuracy of the proposed method was estimated by recovery experiments. Recovery values (Table IV) for B1, B6 and PRML ranged from 100.4-100.6, 100.2-101.2 and 99.3-99.6 $\%$, resp.

Table I. Stationary phase testing

\begin{tabular}{lccccc}
\hline Column & Analyte & $R_{\mathrm{s}}$ & $T_{\mathrm{f}}$ & $\alpha$ & $\mathrm{N}$ \\
\hline Hypersil ODS C18 & B1 & - & 1.34 & - & 3487 \\
$(250 \times 4.6 \mathrm{~mm}, 5 \mu \mathrm{m})$ & B6 & 5.34 & 1.23 & - & 7634 \\
& PRML & 18.79 & 1.54 & 8.752 & 4123 \\
Venusil XBP C8 & B1 & - & 1.33 & - & 3452 \\
$(250 \times 4.6 \mathrm{~mm}, 5 \mu \mathrm{m})$ & B6 & 8.96 & 1.02 & 5.623 & 8976 \\
& PRML & 21.98 & 1.32 & 8.534 & 3576 \\
ACE C8 & B1 & - & 1.11 & - & 6954 \\
$(250 \times 4.6 \mathrm{~mm}, 5 \mu \mathrm{m})$ & B6 & 7.97 & 1.42 & 7.986 & 4532 \\
& PRML & 27.13 & 1.12 & 5.987 & 7684 \\
Agilent Poroshell C18 & B1 & - & 1.35 & - & 3452 \\
$(250 \times 4.6 \mathrm{~mm}, 5 \mu \mathrm{m})$ & B6 & 8.21 & 1.27 & - & 6645 \\
& PRML & 34.99 & 1.16 & 6.987 & 7345 \\
\hline
\end{tabular}

$\alpha$ - selectivity factor, B1 and B6 - vitamins B1 and B6, N- number of theoretical plates per meter, PRML - paracetamol, $R_{\mathrm{s}}-$ chromatographic resolution, $T_{\mathrm{f}}-$ tailing factor 
A. Ali et al:: Stability-indicating HPLC-PDA assay for simultaneous determination of paracetamol, thiamine and pyridoxal phosphate in tablet formulations, Acta Pharm. 69 (2019) 249-259.

Table II. Chromatographic parameters of the optimized HPLC procedure on the Agilent Poroshell C18 column

\begin{tabular}{lccc}
\hline Parameter & B1 & B6 & PRML \\
\hline Retention time $\left(t_{\mathrm{R}^{\prime}}\right.$ min) & 1.89 & 2.41 & 6.29 \\
Tailing factor $\left(T_{\mathrm{f}}\right)$ & 1.48 & 1.39 & 1.52 \\
Chromatographic resolution $\left(R_{\mathrm{S}}\right)$ & - & 4.18 & 17.18 \\
Separation factor $(\alpha)$ & - & - & 8.75 \\
Theoretical plates per meter $(N)$ & 1316 & 1497 & 4633 \\
Retention time RSD $(\%)$ & 0.003 & 0.002 & 0.002 \\
\hline
\end{tabular}

B1 and B6 - vitamins B1 and B6, PRML - paracetamol

Table III. Regression and limiting values data for vitamins B1 and B6 and PRML

\begin{tabular}{lccc}
\hline Parameter & B1 & B6 & PRML \\
\hline Linearity range $\left(\mu \mathrm{g} \mathrm{mL}{ }^{-1}\right)$ & $17.5-30.0$ & $35.0-0.0$ & $87.0-150.0$ \\
Slope $\left(\mathrm{mV} \mathrm{mL} \mathrm{mg}{ }^{-1}\right)$ & 81930 & 34352 & 52895 \\
Intercept $(\mathrm{mV})$ & -3645 & -3145 & 23562 \\
Standard error of slope $\left(\mathrm{mV} \mathrm{mL} \mathrm{mg}{ }^{-1}\right)$ & 952.8 & 386.3 & 689.8 \\
Standard error of intercept $(\mathrm{mV})$ & 22991 & 18646 & 83070 \\
Coefficient of determination $\left(R^{2}\right)$ & 0.9995 & 0.9995 & 0.9993 \\
Limit of detection $(\mathrm{LOD}, \mu \mathrm{g} \mathrm{mL}-1)$ & 0.40 & 0.78 & 2.26 \\
Limit of quantification $\left(\mathrm{LOQ}, \mu \mathrm{mL}^{-1}\right)$ & 1.20 & 2.33 & 6.77 \\
\hline
\end{tabular}

B1 and B6 - vitamins B1 and B6, PRML - paracetamol

Table IV. Accuracy studies of vitamins B1 and B6 and PRML by the new HPLC method

\begin{tabular}{lccc}
\hline Analyte & $\begin{array}{c}\text { Spiked concentration } \\
\left(\mu \mathrm{g} \mathrm{mL}^{-1}\right)\end{array}$ & $\begin{array}{c}\text { Concentration found } \\
\left(\mu \mathrm{gL} \mathrm{m}^{-1}, \text { mean } \pm \text { SEM; RSD, \% }\right)^{\mathrm{a}}\end{array}$ & $\begin{array}{c}\text { Recovery } \\
(\%)\end{array}$ \\
\hline \multirow{3}{*}{ B1 } & 17.5 & $17.6 \pm 0.4 ; 0.6$ & 100.4 \\
& 25.0 & $25.1 \pm 0.5 ; 0.9$ & 100.6 \\
B6 & 30.0 & $30.2 \pm 0.3 ; 0.4$ & 100.6 \\
& 35.0 & $35.3 \pm 0.4 ; 0.6$ & 100.9 \\
& 50.0 & $50.1 \pm 0.5 ; 0.9$ & 100.2 \\
PRML & 60.0 & $60.7 \pm 0.3 ; 0.4$ & 101.2 \\
& 87.0 & $86.4 \pm 0.4 ; 0.6$ & 99.3 \\
& 125.0 & $124.4 \pm 0.5 ; 0.9$ & 99.6 \\
\hline
\end{tabular}

B1 and B6 - vitamins B1 and B6, PRML - paracetamol

${ }^{a} n=3$ 

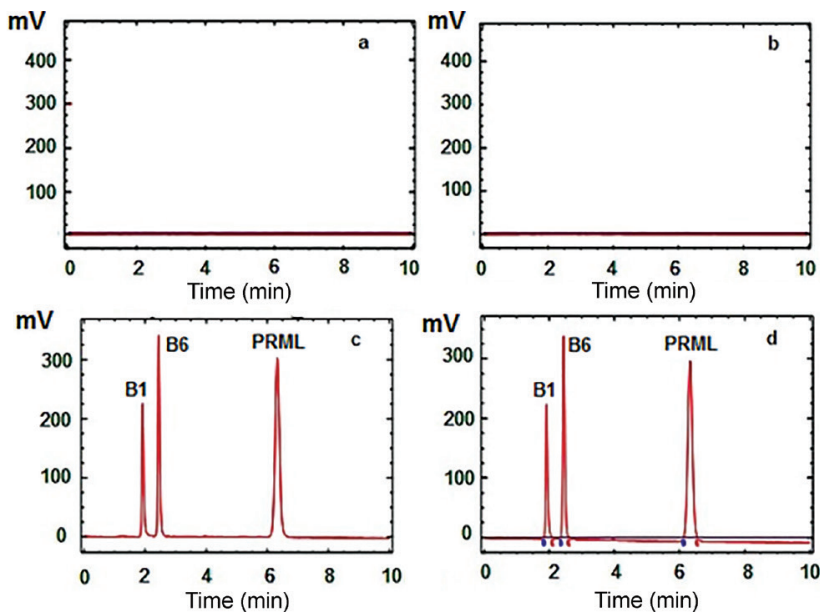

Fig. 3. Typical HPLC chromatograms of: a) mobile phase, b) placebo sample, c) standard mixture (125 $\mu \mathrm{g} \mathrm{mL} \mathrm{m}^{-1}$ PRML, $25 \mu \mathrm{g} \mathrm{mL} \mathrm{m}^{-1} \mathrm{~B} 1$ and $\left.50 \mu \mathrm{g} \mathrm{mL}^{-1} \mathrm{~B} 6\right)$, and d) Neurobedoxine plus tablets (125 $\mu \mathrm{g} \mathrm{mL} \mathrm{m}^{-1}$ PRML, $25 \mu \mathrm{g} \mathrm{mL} \mathrm{m}^{-1} \mathrm{~B} 1$ and $50 \mu \mathrm{g} \mathrm{mL} \mathrm{m}^{-1} \mathrm{~B} 6$ ) after dilution with the mobile phase. B1 and B6 - vitamins $\mathrm{B} 1$ and B6, PRML - paracetamol.

Intra-day and inter-day precision were assessed on the same day and on three consecutive days, resp. The results were within acceptable limits (RSD $<2 \%$ ), as shown in Table V.

Table V. Model precision and accuracy of vitamin B1, B6 and PRML analyses by the new HPLC method

\begin{tabular}{|c|c|c|c|c|c|}
\hline \multirow{3}{*}{ Analyte } & \multicolumn{2}{|c|}{ Within-a-day ${ }^{\mathrm{a}}$} & \multirow{2}{*}{\multicolumn{3}{|c|}{$\begin{array}{c}\text { Inter-day }^{\mathrm{a}} \\
\text { Concentration found } \\
\left(\mu \mathrm{g} \mathrm{mL}^{-1}, \text { mean } \pm \mathrm{SEM} ; \mathrm{RSD}, \%\right)^{\mathrm{a}}\end{array}$}} \\
\hline & \multirow{2}{*}{$\begin{array}{l}\text { Concentra- } \\
\text { tion } \\
\left(\mu \mathrm{g} \mathrm{mL}^{-1}\right)\end{array}$} & \multirow{2}{*}{$\begin{array}{l}\text { Concentration found } \\
\left(\mu \mathrm{g} \mathrm{mL} L^{-1}, \text { mean } \pm\right. \\
\text { SEM; RSD, \% })^{\mathrm{a}}\end{array}$} & & & \\
\hline & & & Day 1 & Day 2 & Day 3 \\
\hline \multirow{3}{*}{ B1 } & 17.5 & $17.6 \pm 0.2 ; 0.3$ & $17.8 \pm 0.6 ; 1.0$ & $17.3 \pm 0.5 ; 0.8$ & $17.6 \pm 0.3 ; 0.5$ \\
\hline & 25.0 & $25.3 \pm 0.3 ; 0.5$ & $25.2 \pm 0.5 ; 0.8$ & $24.8 \pm 0.5 ; 0.8$ & $25.3 \pm 0.7 ; 1.3$ \\
\hline & 30.0 & $29.9 \pm 0.3 ; 0.5$ & $30.7 \pm 0.3 ; 0.5$ & $30.4 \pm 0.6 ; 1.0$ & $30.1 \pm 0.2 ; 0.4$ \\
\hline \multirow{3}{*}{ B6 } & 35.0 & $35.4 \pm 0.5 ; 0.8$ & $35.6 \pm 0.7 ; 1.2$ & $35.3 \pm 0.7 ; 1.2$ & $35.2 \pm 0.5 ; 0.8$ \\
\hline & 50.0 & $50.8 \pm 0.5 ; 0.9$ & $49.8 \pm 0.6 ; 1.1$ & $50.8 \pm 0.8 ; 1.4$ & $50.8 \pm 0.7 ; 1.1$ \\
\hline & 60.0 & $61.3 \pm 0.5 ; 0.8$ & $61.7 \pm 0.5 ; 0.9$ & $60.6 \pm 0.9 ; 1.4$ & $59.6 \pm 0.5 ; 0.9$ \\
\hline \multirow{3}{*}{ PRML } & 87.0 & $89.3 \pm 0.1 ; 0.2$ & $88.2 \pm 0.9 ; 1.5$ & $88.2 \pm 0.9 ; 1.4$ & $88.6 \pm 0.6 ; 1.0$ \\
\hline & 125.0 & $128.4 \pm 0.7 ; 1.2$ & $127.4 \pm 0.5 ; 0.9$ & $126.8 \pm 0.6 ; 0.9$ & $128.1 \pm 0.3 ; 0.5$ \\
\hline & 150.0 & $153.0 \pm 0.3 ; 0.6$ & $153.8 \pm 0.8 ; 1.4$ & $150.4 \pm 1.0 ; 1.7$ & $152.9 \pm 0.5 ; 0.8$ \\
\hline
\end{tabular}

B1 and B6 - vitamins B1 and B6, PRML - paracetamol a $n=5$. 
A. Ali et al:: Stability-indicating HPLC-PDA assay for simultaneous determination of paracetamol, thiamine and pyridoxal phosphate in tablet formulations, Acta Pharm. 69 (2019) 249-259.

Table VI. Method robustness for vitamins B1, B6, and PRML in tablets

\begin{tabular}{lllllllllll}
\hline \multirow{2}{*}{$\begin{array}{l}\text { Chromatographic } \\
\text { conditions }\end{array}$} & \multicolumn{3}{c}{ B1 } & \multicolumn{3}{c}{ B6 } & \multicolumn{3}{c}{ PRML } \\
\cline { 2 - 10 } & $\begin{array}{l}\text { Assay } \\
(\%)\end{array}$ & $\begin{array}{l}t_{\mathrm{R}} \\
(\mathrm{min})\end{array}$ & $N$ & $\begin{array}{l}\text { Assay } \\
(\%)\end{array}$ & $\begin{array}{l}t_{\mathrm{R}} \\
(\mathrm{min})\end{array}$ & $N$ & $\begin{array}{l}\text { Assay } \\
(\%)\end{array}$ & $\begin{array}{l}t_{\mathrm{R}} \\
(\mathrm{min})\end{array}$ & $N$ \\
\hline Flow rate $1.9\left(\mathrm{~mL} \mathrm{~min}^{-1}\right)$ & 100.3 & 1.86 & 3564 & 100.9 & 2.38 & 6645 & 99.3 & 6.26 & 7350 \\
Flow rate $1.7\left(\mathrm{~mL} \mathrm{~min}^{-1}\right)$ & 100.2 & 1.93 & 3576 & 100.3 & 2.45 & 6623 & 99.7 & 6.31 & 7324 \\
Column temp. $\left(45^{\circ} \mathrm{C}\right)$ & 101.3 & 1.92 & 3579 & 99.5 & 2.44 & 6635 & 101.3 & 6.33 & 7367 \\
Column temp. $\left(35^{\circ} \mathrm{C}\right)$ & 101.7 & 1.93 & 3591 & 99.9 & 2.39 & 6667 & 101.6 & 6.32 & 7354 \\
Wavelength $(272 \mathrm{~nm})$ & 100.8 & 1.89 & 3518 & 101.3 & 2.46 & 6645 & 100.7 & 6.34 & 7329 \\
Wavelength $(268 \mathrm{~nm})$ & 100.7 & 1.90 & 3542 & 101.0 & 2.44 & 6668 & 100.4 & 6.33 & 7366 \\
pH 3.1 & 99.3 & 1.90 & 3555 & 100.3 & 2.38 & 6623 & 100.1 & 6.29 & 7365 \\
pH 2.9 & 99.9 & 1.92 & 3563 & 100.6 & 2.40 & 6634 & 100.4 & 6.27 & 7325 \\
\hline
\end{tabular}

B1 and B6 - vitamins B1 and B6, PRML - paracetamol, N-number of theoretical plates per meter
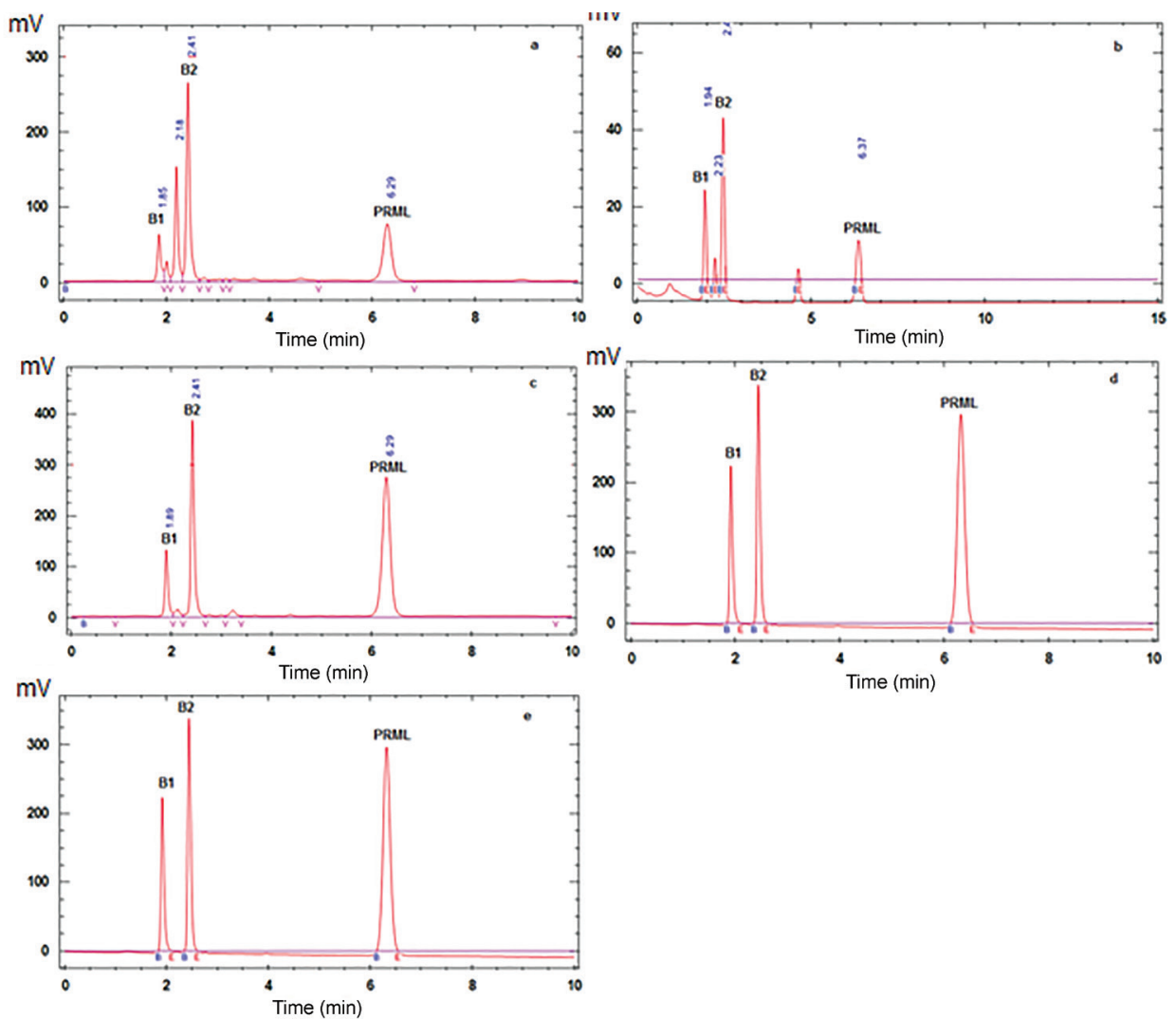

Fig. 4. Typical HPLC chromatograms under stress conditions: a) acidic, b) basic, c) oxidative, d) photolytic, and e) thermal. B1 and B6 - vitamins B1 and B6, PRML - paracetamol. 
A. Ali et al:: Stability-indicating HPLC-PDA assay for simultaneous determination of paracetamol, thiamine and pyridoxal phosphate in tablet formulations, Acta Pharm. 69 (2019) 249-259.

Table VII. Force degradation studies for vitamins B1 and B6 and PRML in tablets

\begin{tabular}{|c|c|c|c|}
\hline Stress conditions & Component & Assay (\%) & Extent of degradation \\
\hline \multirow[t]{3}{*}{$\mathrm{HCl}\left(0.1 \mathrm{~mol} \mathrm{~L}^{-1}, 12 \mathrm{~h}\right)$} & B1 & 53.3 & Substantial \\
\hline & B6 & 88.3 & Substantial \\
\hline & PRML & 60.3 & Substantial \\
\hline \multirow[t]{3}{*}{$\mathrm{NaOH}\left(0.1 \mathrm{~mol} \mathrm{~L}^{-1}, 12 \mathrm{~h}\right)$} & B1 & 98.2 & None \\
\hline & B6 & 87.3 & Substantial \\
\hline & PRML & 70.9 & Substantial \\
\hline \multirow[t]{3}{*}{$\mathrm{H}_{2} \mathrm{O}_{2}(3 \%, 12 \mathrm{~h})$} & B1 & 94.3 & Slight \\
\hline & B6 & 97.5 & None \\
\hline & PRML & 94.3 & Slight \\
\hline \multirow[t]{3}{*}{ UV light (254 nm, $24 \mathrm{~h}$ ) } & B1 & 99.4 & None \\
\hline & B6 & 98.8 & None \\
\hline & PRML & 100.2 & None \\
\hline \multirow[t]{3}{*}{ Heating $\left(70^{\circ} \mathrm{C}, 6 \mathrm{~h}\right)$} & B1 & 99.3 & None \\
\hline & B6 & 98.9 & None \\
\hline & PRML & 99.9 & None \\
\hline
\end{tabular}

B1 and B6 - vitamins B1 and B6, PRML - paracetamol

Table VIII. Commercial tablet assay for B1, B6 and PRML

\begin{tabular}{|c|c|c|c|c|c|c|c|c|}
\hline Product & Analyte & $\begin{array}{l}\text { Taken from } \\
\text { tablet } \\
\left(\mu g \mathrm{~mL}^{-1}\right)\end{array}$ & $\begin{array}{l}\text { Found in } \\
\text { tablet } \\
\left(\mu g \mathrm{~mL}^{-1}\right)^{\mathrm{a}, \mathrm{b}}\end{array}$ & $\begin{array}{l}\text { RSD } \\
(\%)^{b}\end{array}$ & $\begin{array}{l}\text { Analyte } \\
\text { added } \\
\left(\mu \mathrm{g} \mathrm{mL} \mathrm{L}^{-1}\right)\end{array}$ & $\begin{array}{l}\text { Total conc. } \\
\text { found } \\
\left(\mu \mathrm{g} \mathrm{mL}^{-1}\right)\end{array}$ & $\begin{array}{l}\text { Recovery } \\
(\%)^{\mathrm{a}, \mathrm{b}}\end{array}$ & $\begin{array}{l}\text { RSD } \\
(\%)^{b}\end{array}$ \\
\hline \multirow{9}{*}{$\begin{array}{l}\text { Neuro } \\
\text { Bedoxine } \\
\text { Plus } \\
\text { tablets }^{c}\end{array}$} & \multirow[t]{3}{*}{ B1 } & \multirow[t]{3}{*}{50} & \multirow[t]{3}{*}{$50.5 \pm 0.1$} & \multirow[t]{3}{*}{0.5} & 40.0 & 90.9 & $100.5 \pm 0.2$ & 0.6 \\
\hline & & & & & 50.0 & 100.9 & $100.3 \pm 0.2$ & 0.7 \\
\hline & & & & & 60.0 & 111.1 & $100.5 \pm 0.2$ & 0.5 \\
\hline & \multirow[t]{3}{*}{ B6 } & \multirow[t]{3}{*}{100} & \multirow[t]{3}{*}{$101.6 \pm 0.3$} & \multirow[t]{3}{*}{0.9} & 80.0 & 181.5 & $99.9 \pm 0.2$ & 0.7 \\
\hline & & & & & 100.0 & 201.3 & $99.8 \pm 0.2$ & 0.5 \\
\hline & & & & & 120.0 & 222.8 & $100.5 \pm 0.3$ & 0.9 \\
\hline & \multirow[t]{3}{*}{ PRML } & \multirow[t]{3}{*}{250} & \multirow[t]{3}{*}{$248.9 \pm 0.7$} & \multirow[t]{3}{*}{0.9} & 200.0 & 450.1 & $100.3 \pm 0.3$ & 0.8 \\
\hline & & & & & 250.0 & 500.7 & $100.4 \pm 0.1$ & 0.4 \\
\hline & & & & & 300.0 & 551.5 & $100.5 \pm 0.2$ & 0.6 \\
\hline
\end{tabular}

B1 and B6 - vitamins B1 and B6, PRML - paracetamol

${ }^{\mathrm{a}}$ Mean \pm SEM.

${ }^{\mathrm{b}} n=10$.

c Neuro Bedoxine Plus tablet label claim: 250 mg PRML, 50 mg B1 and 100 mg B6. 
Concentration of three APIs in the commercial tablet formulation was estimated by the proposed HPLC method. It was evidenced that the proposed HPLC method was precise (RSD 0.4-0.9\%) and accurate enough (recovery 99.8-100.5\%) for successful routine analyses (Table VIII).

\section{CONCLUSIONS}

In the literature, no stability indicating HPLC method is found available for simultaneous determination of paracetamol, thiamine, and pyridoxal phosphate. Stress testing under ICH specifications indicated that the proposed HPLC method is stability indicating and selective. The total run time of analysis was found to be less than $7 \mathrm{~min}$. The proposed method showed high recovery and precision in the presence of excipients used in the formulation. It might be assumed that the proposed HPLC method is simple, precise, accurate, linear and sufficiently selective for routine simultaneous determination of paracetamol, thiamine and pyridoxal phosphate.

\section{REFERENCES}

1. C. Celma, J. Allue, J. Prunonosa, C. Peraire and R. Obach, Simultaneous determination of paracetamol and chlorpheniramine in human plasma by liquid chromatography-tandem mass spectrometry, J. Chromatogr. A 870 (2000) 77-86; https://doi.org/10.1016/S0021-9673(99)01252-2

2. S. Vidović, B. Stojanović, J. Veljković, L. Pražić-Arsić, G. Roglić and D. Manojlović, Simultaneous determination of some water-soluble vitamins and preservatives in multivitamin syrup by validated stability-indicating high-performance liquid chromatography method, J. Chromatogr. A 1202 (2008) 155-162; https://doi.org/10.1016/j.chroma.2008.06.039

3. R. Bishop, G. Davidson, I. Holmes and B. Ruck, Virus particles in epithelial cells of duodenal mucosa from children with acute non-bacterial gastroenteritis, Lancet 302 (1973) 1281-1283; https:// doi.org/10.1016/S0140-6736(73)92867-5

4. H. Mcdevitt and W. Bodmer, HL-A, immune-response genes, and disease, Lancet 303 (1974) 12691275; https://doi.org/10.1016/S0140-6736(74)90021-X

5. M. T. Borin and J. W. Ayres, Single dose bioavailability of acetaminophen following oral administration, Int. J. Pharm. 54 (1989) 199-209; https://doi.org/10.1016/0378-5173(89)90097-5

6. Z. Chen, B. Chen and S. Yao, High-performance liquid chromatography/electrospray ionizationmass spectrometry for simultaneous determination of taurine and 10 water-soluble vitamins in multivitamin tablets, Anal. Chim. Acta 569 (2006) 169-175; https://doi.org/10.1016/j.aca.2006.03.099

7. M. Ciulu, S. Solinas, I. Floris, A. Panzanelli, M. I. Pilo, P. C. Piu, N. Spano and G. Sanna, RP-HPLC determination of water-soluble vitamins in honey, Talanta 83 (2011) 924-929; https://doi. org/10.1016/j.talanta.2010.10.059

8. D. Emre and N. Özaltın, Simultaneous determination of paracetamol, caffeine and propyphenazone in ternary mixtures by micellar electrokinetic capillary chromatography, J. Chromatogr. B 847 (2007) 126-132; https://doi.org/10.1016/j.jchromb.2006.09.036

9. H. Şenyuva and T. Özden, Simultaneous high-performance liquid chromatographic determination of paracetamol, phenylephrine $\mathrm{HCl}$, and chlorpheniramine maleate in pharmaceutical dosage forms, J. Chromatogr. Sci. 40 (2002) 97-100; https://doi.org/10.1093/chromsci/40.2.97

10. U. Höller, C. Brodhag, A. Knöbel, P. Hofmann and V. Spitzer, Automated determination of selected water-soluble vitamins in tablets using a bench-top robotic system coupled to reversedphase (RP-18) HPLC with UV detection, J. Pharm. Biomed. Anal. 31 (2003) 151-158; https://doi. org/10.1016/S0731-7085(02)00574-5 
11. K. Callmer and L. Davies, Separation and determination of vitamin $B_{1}, B_{2}, B_{6}$ and nicotinamide in commercial vitamin preparations using high performance cation-exchange chromatography, Chromatographia 7 (1974) 644-650; https://doi.org/10.1007/BF02290508

12. M. Amin and J. Reusch, High-performance liquid chromatography of water-soluble vitamins. Part 3. Simultaneous determination of vitamins $\mathrm{B}_{1}, \mathrm{~B}_{2}, \mathrm{~B}_{6}, \mathrm{~B}_{12}$ and $\mathrm{C}$, nicotinamide and folic acid in capsule preparations by ion-pair reversed-phase high-performance liquid chromatography, Analyst 112 (1987) 989-991; https://doi.org/10.1039/AN9871200989

13. B. Morelli, Determination of a quaternary mixture of vitamins B6, B1, and B12 and uridine 5'-triphosphate, by derivative spectrophotometry, J. Pharm. Sci. 84 (1995) 34-37; https://doi.org/10.1002/ jps.2600840109

14. P. Moreno and V. Salvado, Determination of eight water-and fat-soluble vitamins in multi-vitamin pharmaceutical formulations by high-performance liquid chromatography, J. Chromatogr. A $\mathbf{8 7 0}$ (2000) 207-215; https://doi.org/10.1016/S0021-9673(99)01021-3

15. A. Lebiedzińska, M. L. Marszałł, J. Kuta and P. Szefer, Reversed-phase high-performance liquid chromatography method with coulometric electrochemical and ultraviolet detection for the quantification of vitamins B1 (thiamine), B6 (pyridoxamine, pyridoxal and pyridoxine) and B12 in animal and plant foods, J. Chromatogr. A 1173 (2007) 71-80; https://doi.org/10.1016/j.chroma.2007.09.072

16. A. Gliszczyńska-Świgło and I. Rybicka, Simultaneous determination of caffeine and water-soluble vitamins in energy drinks by HPLC with photodiode array and fluorescence detection, Food Anal. Methods 8 (2015) 139-146; https://doi.org/10.1007/s12161-014-9880-0

17. A. El-Gindy, K. A.-S. Attia, M. W. Nassar, H. H. Abu Seada and M. A.-S. Shoeib, HPLC method for determination of paracetamol, psedoephedrine, triprolidine, methylparaben, propylparaben, sodium benzoate, and their related substances in pharmaceutical syrup, J. Liq. Chromatogr. Relat. Technol. 36 (2013) 1251-1263; https://doi.org/10.1080/10826076.2012.685922

18. M. I. Walash, F. Ibrahim and S. Abo El Abass, Development and validation of HPLC method for simultaneous estimation of famotidine, paracetamol and diclofenac in their raw materials and pharmaceutical formulation, Anal. Chem. Lett. 7 (2017) 421-437; https://doi.org/10.1080/22297928.2 017.1353921

19. M. L. Marszałł, A. Lebiedzińska, W. Czarnowski and P. Szefer, High-performance liquid chromatography method for the simultaneous determination of thiamine hydrochloride, pyridoxine hydrochloride and cyanocobalamin in pharmaceutical formulations using coulometric electrochemical and ultraviolet detection, J. Chromatogr. A 1094 (2005) 91-98; https://doi.org/10.1016/j. chroma.2005.07.091

20. P. Lynch and I. S. Young, Determination of thiamine by high-performance liquid chromatography, J. Chromatogr. A 881 (2000) 267-284; https://doi.org/10.1016/S0021-9673(00)00089-3

21. K. Ishii, K. Sarai, H. Sanemori and T. Kawasaki, Analysis of thiamine and its phosphate esters by high-performance liquid chromatography, Anal. Biochem. 97 (1979) 191-195; https:/doi. org/10.1016/0003-2697(79)90345-2

22. International Conference on Harmonisation of Technical Requirements for Registration of Pharmaceuticals for Human Use, ICH Harmonised Tripartite Guideline - Validation of Analytical Procedures: Text and Methodology Q2(R1), Current Step 4 version, November 2005.

23. I. Taverniers, E. Van Bockstaele and M. De Loose, Analytical Method Validation and Quality Assurance, in Pharmaceutical Sciences Encyclopedia: Drug Discovery, Development, and Manufacturing, Wiley, Hoboken (NJ) 2010, pp. 1-48.

24. A. Rignall, ICHQ1A(R2) Stability Testing of New Drug Substance and Product and ICHQ1C Stability Testing of New Dosage Forms (chapter 1), in ICH Quality Guidelines: An Implementation Guide (Eds. A. Teasdale, D. Elder and R. W. Nims), Wiley, Hoboken (NJ) 2017, pp. 3-44. 